\title{
PELANGGARAN PRINSIP KERJASAMA DALAM DEBAT KANDIDAT CALON WAKIL GUBERNUR JAWA TIMUR TAHUN 2018
}

\author{
Khusnul Khotimah \\ Fakultas Ilmu Pendidikan, Universitas Trunojoyo Madura \\ Khusnul.khotimah@trunojoyo.ac.id
}

\begin{abstract}
ABSTRAK
Penelitian ini bertujuan untuk mendeskripsikan pelanggaran prinsip kerjasama dalam debat Calon Wakil Gubernur Jawa Timur tahun 2018. Metode penelitian yang digunakan dalam penelitian ini adalah motode deskriptif kualitatif. Analisis dilaksanakan dengan uturan proses yang sudah disusun oleh peneliti. Hasil penelitian menemukan bahwa pelanggaran maksim kuantitas terjadi saat Emil menjawab pertanyaaan dari Puti dengan berlebihan. Pelanggaran maksim kualitas terjadi saat Puti menyebutkan desa yang ia kunjungi dengan penggunaan kata kalau tidak salah.pelanggaran maksim relevansi terjadi saat Emil menanyakan mengenai rata-rata stanting Jawa Timur dan Puti tidak menjawab pertanyaan tersebut. Sedangkan pelanggaran maksim cara terjadi saat puti bertanya tetapi ia terlalu bertele-tele dengan menjelaskan hal lain diluar pertanyaan yang ia sampaiakan. Berdasarkan analisis yang telah dilaksanakan diketahui bahwa didapatkan pelanggaran dalam semua maksim prinsip kerjasama dalam debat yang dianalisis meliputi maksim kuantitas, maksim kualitas, maksim relevansi, dan maksim cara.
\end{abstract}

Kata Kunci: Debat, CAWAGUB, pelanggaran prinsip kerjasama.

\begin{abstract}
The research aim to describe violations principle of conversation candidate of guvernor's deputy Jawa Timur debate 2018. Descriptive qualitative method used in this research. The analysis used the proses from researcher. The result of this research vioation maxims of quantity happen when Emil's remain answer question from Puti's. Violation maxims of quality when Puti's not convinced call name of the visited vilage. Violation maxims of relevance when Puti's answer about the stanting periodic. Violation maxims of manner when Puti's ques brief and oederly. From the analysis we can find all of the vi0lation maxims principle of conversation.
\end{abstract}

Keywords: debate, CAWAGUB, violation principle of conversation.

\section{PENDAHULUAN}

Sastra merupakan wujud gagasan seseorang melalui pandangan terhadap lingkungan sosial yang berada di sekelilingnya dengan menggunakan bahasa yang indah. Sastra hadir sebagai hasil perenungan terhadap fenomen yang ada. Sastra sebagai karya fiksi memiliki pendalaman yang lebih mendalam, bukan sekadar hanya 
cerita khayal atau angan dari pengarang saja, melainkan wujud dari kreatifitas pengarang dalam menggali dan mengelola gagasan yang ada dalam pikirannya.

Bahasa menurut Kridalaksana (dalam Chaer, 2012:32) adalah sistem lambang bunyi yang bersifat arbitrer yang digunakan oleh para anggota kelompok sosial untuk bekerja sama, berkomunikasi, dan mengidentifikasikan diri. Bahasa tidak pernah lepas dari kehidupan masyarakat sehari-hari. Segala hal yang dilaksanakan oleh masyarakat pasti berhubungan dengan bahasa, walaupun terkadang bahasa yang digunakan tidak diucapkan secara verbal.

Bahasa sebagai alat berkomunikasi sehari-hari menjadi pemegang peran penting dalam kehidupan bermasyarakat. Tanpa bahasa komunikasi antar indivudu dan kelompok akan terasa lebih sulit. Segala aspek kehidupan juga memerlukan bahasa sebagai alat penyampaiannya termasuk kegiatan bermasyarakat, proses pendidikan bahkan dalam ranah politik juga memerlukan bahsa sebagai alat untuk mencari dukungan dalam sebuah partai.

Pragmatik merupakan kajian ilmu yang mempelajari makna berdasarkan konteks yang mengikutinya. Menurut Levinson (dalam Nadar, 2013:4) pragmatik merupakan kajian hubungan antara b.ahasa dan konteks yang tergramatikalisasi atau terkodifikasi dalam struktur bahasa. Dalam pragmatik suatu makna tidak hanya dilihat secara leksikal atau kosa kata yang bersangkutan, melainkan konteks atau sesuatu yang lain yang bersangkutan saat kalimat tersebut diujarkan.

Pragmatik sebagai kajian makna secara konteks sering kita temukan dalam kehidupan sehari-hari. Ada salah satu kajian pragmatik yang menarik untuk dianalisis. Kajian tersebut adalah mengenai prinsip kerjasama. Prinsip kerjasama di sini adalah kerjasama antara penutur dengan mitra tutur sehingga apa yang disampaikan dapat dipahami dengan baik. Wijana (1996:45) menyebutkan bahwa prinsip kerjasama sama halnya dengan proses komunikadi yang wajar dilaksanakan oleh masyarakat sehingga tujuan pembicaraan atau percakapan mampu dicapai. Seorang penutur pasti memiliki informasi yang ingin disampaikan atau diperoleh dalam sebuah percakapan, oleh karena itu prinsip kerjasama sangat diperlukan dalam proses percakapan.

Analisis yang akan dilaksanakan mengarah pada pelanggaran prinsip kerjasama yang meliputi maksim kuantitas, maksim kualitas, maksim relevansi, dan maksim 
cara. Pemilihan pelanggaran prinsip kerjasama ini dikarenakan masyaarakat indonesia banyak yang sering berkomunikasi dengan mengtakan sesuatu tidak secara langsung atau sering dikenal dengan basa-basi. Komunikasi semacam ini banyak dipengaruhi oleh latar belakang sosial budaya, kesopanan, toleransi, dan bahkan untuk mempererat hubungan kekeluargaan antar penutur. Hal lain yang terindentifikasi adalah adanya pengalihan topik dari salah satu pihak penutur untuk mendapatkan atau memberikan informasi di luar yang diinginkan oleh lawan tutur.

Pelanggaran prinsip kerjasama dalam analisis kali ini adalah dalam debat Calon Wakil Gubernur (CAWAGUB) Jawa Timur 2018. Tujuan dari penelitian ini adalah untuk mendeskripsikan pelanggaran prinsip kerjasama dalam debat Calon Wakil Gubernur Jawa Timur tahun 2018. Debat yang dianalis adalah debat yang dilaksanakan pada 26 Juni 2018 yang diakses dari laman youtube CNN Indonesia, yaitu malam sebelum pemungutan suara yang yang dilaksanakan serentak di Jawa Timur pada 27 Juni 2018. Ada dua pasang kandidat yang bersaing dalam pemilihan ukepala daerah kali ini. Nomor urut satu ditempai oleh pasangan Khofifah Indar Parawangsa yang berpasangan dengan Emil Dardak, serta nomor urut dua pasangan Saifullah Yusuf dengan Puti Guntur Soekarno.

Prinsip kerjasama perlu diperhatikan dalam sebuah komunikasi yang dilaksanakan oleh seorang penutur dengan lawan tuturnya. Menurut Wijana (1996: 45) komunikasi yang wajar dapat diasumsikan bahwa seseorang penutur mengartikulasikan ujaran dengan maksud untuk mengomunikasikan sesuatu kepada lawan bicaranya dan berharap lawan bicara dapat memahami apa yang hendak dibicarakan. Penutur selalu berusaha agar tuturannya selalu relevan dengan konteks, jelas dan mudah dipahami, padat dan ringkas, dan selalu pada persoalan, sehingga tidak menghabiskan waktu lawan bicaranya.

Grice (dalam Nadar, 2013:24) merumuskan bahwa prinsip kerjasama berbunyi sebagai berikut: "Berikanlah kontribusi anda dalam percakapan sesuai dengan kebutuhan, pada tingkat dimana percakapan tersebut berlangsung, sesuai dengan maksud dan tujuan dimana anda terlibat". Maksudnya adalah ketika kita melaksanakan sebuah percakapan, kita perlu mempertimbangkan kebutuhan percakapan atau jawaban yang dibutuhkan, kemudian kita juga harus memperhatikan 
dimana kita melaksanaan percakapan, serta maksud dan tujuan percakapan tersebut sehingga apa yang dibicarakan tidak menyebar ke hal lain yang tidak diperlukan.

Ada empat maksim dalam prinsip kerjasama menutur Grice yaitu: maksim kuantitas, maksim kualitas, maksim relevansi, dan maksim cara. Berikut adalah penjabaran dari setiap maksim yang sudah disebutkan diatas berdasarkan penjabaran Wijana (1996) dan Nadar (2013).

1. Maksim Kuantitas (Maxims of Quantity)

Maksim kualitas menghendaki setiap peserta pertuturan memberikan kontribusi yang secukupnya atau sebanyak yang dibutuhkan oleh lawan bicaranya. Informasi yang dibutuhkan disini adalah yang sesuai dengaan tujuan atau maksud pembicaraan. Seorang penutur juga dilarang memberikan informasi ang berlebihan dari apa yang dibutuhkan oleh lawan tutur. Pada dasar apa yang kita berikan pada lawan tutur sesuai dengan jawaban yang mereka inginkan. Misalnya seseorang bertanya siapa nama kita, tidak mugkin kita menjawab panjang lebar, berbeda jika orang tersebut meminta kita untuk menceritak siapa diri kita, maka jawaban yang diinginkan adalah jawaban panjang lebar mengenai siapa diri kita.

2. Maksim kualitas (Maxims of Quality)

Maksim kualitas merupakan maksim yang mengharuskan seorang penutur untuk mengatakan apa yang sebenarnya. Tidak mengatakan hal yang belum pasti kebenarannya atau tidak dapat dibuktikan kebenarannya. Secara sederhana maksim ini melarang seorang penutur untuk berbohong kepada lawan lawan tutur. Pelanggaran maksim kualitas sering terjadi dengan alasan-alasan tertentu, misalnya untuk memberikan jawaban atas kesalahan yang dialksanakan orang lain atau juga sebagai lelucon untuk membuat percakapan yang lebih santai. Contoh maksim kualitas adalah jika seseorang bertanya apakah kita sudah makan, maka kita harus mengatakan dengan jujur apakah sudah atau belum tanpa disertai dengan alasan yang akhirnya melanggar prinsip kerjasama.

\section{Maksim Relevansi (Maxims of Relevance)}

Maksim relevansi mengharuskan setiap peserta percakapan memberikan kontribusi yang relevan dengan masalah yang sedang dibicarakan. Dalam sebuah percakapan seorang penutur pastilah membutuhkan informasi sesuai yang diharapkan sehingga lawan tutur harus memberikan jawaban yang sesuai atau relevan dengan apa 
yang ditanyakan. Meskipun apa yang dikatakan oleh lawan tutur masih meupakan hal dapat berkalitan tetapi haal ini tetap saja melanggar maksim relevansi. Maksim relevansi tidak selalu harus sesuai dengan makna kata yang diujarkan, tetapi juga dapat implikasi yang saling dipahami antar penutur sehingga apa yang dibutuhkan dan diberikan tetap relevan.

4. Maksim Cara atau Pelaksanaan (Maxims of Manner)

Maksim ini mengharuskan setiap peserta tutur berbicara secara langsung, tidak kabur, tidak taksa, tidak berlebih-lebihan dan runtut. Dalam maksim ini seorang penutur juga diharuskan menafsirkan kata-kata yang digunakan oleh lawan bicranya secara taksa berdaarkan konteka pemakainnya. Hal ini dimaksudkan untuk dapat saling terjalin kerjasama seskipun salah satu penutur melanggar prinsip kerjasama.

\section{METODOLOGI PENELITIAN}

Penelitian ini menggunakan pendekatan kualitatif dengan metode deskriptif. Pendekatan kualitatif (qualitative approach) merupakan suatu mekanisme kerja penelitian yang mengandalkan uraian deskriptif kata atau kalimat yang disusun secara cermat dan sistematis mulai dari menghimpun data hingga menafsirkan dan melaporkan hasil penelitian (Ibrahim, 2015:55). Sedangkan, metode deskriptif menurut Arikunto (2013:3) berarti memaparkan atau menggambarkan sesuatu, misal keadaan, kondisi, situasi, peristiwa, kegiatan, dan sebagainya. Pendekatan kualitatif deskriptif dalam penelitian ini digunakan untuk menjelaskan secara deskriptif mengenai pelamggaran prinsip kerjasama dalam debat kandidat CAWAGUB Jatim tahun 2018 dengan menggunakan teknik rekam, simak, dan catat.

Analisis dilaksanakan dengan uturan proses yang sudah disusun oleh peneliti. Diawali dengan mendapatkan rekaman debat yang merupakan bahan analisis, mentranskrip hasil debat, membaca keseluruhan transkrip, mengidentifikasi dan menemukan pelanggaran prinsip kerjamasa dalam transkrip, menemukan alasanalasan pelanggaran atau proses analisis, mendeskripsikan analisis, dan membuat kesimpulan. Identifikasi atau analisis yang dilaksanakan dengan mempertimbangkan prinsip kerjasama yang meliputi maksim kuantitas, maksim kualitas, maksim relevansi dan maksim cara atau pelaksanaan. 


\section{PEMBAHASAN}

Debat CAWAGUB Jawa Timur 2018 memberikan kesempatan bertanya pada wakil kandidat nomor urut dua yaitu Puti Guntur Soekarno. Pada kesempatan tersebut beliau menanyakan mengenai tingkat kemiskinan di Kabupaten Trenggalek serta program Milenial job center yang menjadi program unggulan Emil Dardak yang saat mencalonkan sebagai wakil gubernur masih menjadi Bupati Trenggalek.Sedangkan pada kesempatan kedua Emil menanyakan mengenai angka gizi buruk di Jawa Tmur. Berdasarkan dua pertanyaan tersebut peneliti akan menganalisis pelanggaran prinsip kerjasama yang terjadi dalam debat.

\section{Pelanggaran Maksim Kuantitas}

Maksim kuantitas menuntut penutur untuk memberikan jawaban sesuai dengan pertanyaan yang diberikan. Hal ini banyak dilanggar dalam proses debat yang dilaksanakan. Kedua kandidat cenderung memberikan banyak argumen dan pendukung yang sebenarnya tidak diinginkan oleh lawan bicara. Tetapi berbagai argumen dan penguatan ini juga memiliki alasan untuk memperkuat jawaban yang diberikan juga untuk memperoleh pembenaran dari pendengar atau peserta debat yang lainnya diluar penanya. Selain itu debat ini dilaksanakan untuk menarik pemilih atau meyakinkan pemilih mengenai kandidat yang mereka pilih.

Pelanggaran tersebut dapat dilihat saat Puti bertanya mengenai Milenial Job Center yang di awali dengan berbagai penjelasan megenai tingkat kemiskinan di Jawa timur. Jawaban yang diberikan lebih banyak membahas mengenai tingkat kemiskinan, sedangkan dari pertanyaan yang diutarakan adalah pada program yang dimiliki oleh Emil. Penjelasan yang panjang lebar diberikan oleh Emil tidak ditemukan jawaban atas komitmennya mengenai program Milenial Job Center, dia hanya panjang lebar membahas mengenai pengangguran itu sendiri. Hal ini dapat dilihat pada kutipan transkrip berikut.

Puti : "Baik, terima kasih, Mas Emil ada satu pertanyaan yang akan saya sampaikan pada Mas Emil. Kemarin itu saya sempat jalan-jalan juga menyapa warga Kabupaten Trenggalek. Lalu saya melihat bahwa di dalam data BPS 2016 tingkat kemiskinan di Kabupaten Trenggalek itu naik 0,17 \%, lalu kemudian 2017 tingkat pengangguran terbuka Kabupaten Trenggalek juga naik mas 37\% dari 1960 sampai ke angka 
13.000. sementara saya tahu mas emil punya program yang begitu baik adalah Milenial job center lalu bagaimana komitmen mas Emil?".

Emil : "Ini pernyataan yang sudah bisa diprediksi, karena sudah banyak yang bisa dipatahkan dari pertanyaan ini, jadi kalau bicara soal kemiskinan tolong dicek angkat yang tertera di akhir. Malah penurunan kemiskinan kita ini hampir bisa melebihi penurunan kemiskinan di provinsi. Jadi, angkanya sekarang sudah kepala 12 cek di BPS saja silahkan jangan teriak. Nah yang kedua, soal pengangguran asal mbak tahu, ini yag perlu dicek itu namanya timeseries analitis jadi jangan dilihat secara statistik, lihatnya timeseries selama moving evering misalnya tiga periode atau lima periode. Jadi tahun 2015 itu angka pengangguran itu ada diatas 4\% kemudian diangkat ditahun 2016 ada di angka 2\% angka ini ada anomali dari angka drai BPS provinsi hasilnya dari pak WAGUB, artinya bahwa kami punya tingkat pengangguran dibawah 4\%, lalu sekarang di 2017 sudah di bawah $3,4 \%$, artinya kalau kita merujuk kesitu. Sebenaarnya pengangguran turun. Kenapa turun.. karena kami memang melakukan diversifikasi".

\section{Pelanggaran Maksim Kualitas}

Pelanggaran pada maksim kualitas berkenaan dengan kebenaran yang diutarakan oleh penutur. Pada debat yang dilaksanaakan saat Puti menyebutkan desa yang beliau datangi, beliau tidak dengan pasti menyebutkan desa tersebut, tetapi masih menggunakan kata kalau saya tidak salah sebut. Hal tersebut memberikan kesan bahwa maksim kualitas yang digunakan oleh Puti masih belum bisa ia pastikan dengan benar kebenarannya, bahkan ia masih meragukan kebenarannya. Hal ini dapat dilihat pada kutipan transkrip berikut.

Puti : "Ya, yang pasti yang saya datangi di trenggalek Mas Emil, ini kalau tidak salah desa yang saya datangi kalau saya tidak salah sebut Desa Krayen itu saya bertemu dengan ibu dan bayinya terkena stanting artinya tumbuh kembang dari bayi itu".

\section{Pelanggaran Maksim Relevansi}

Pada maksim relevansi pelanggaran yang terjadi adalah tidak sesuainya jawaban atas pertanyaan yang diberikan oleh lawan tutur. Ditemukan dalam debat bahwa saat Emil menanyakan mengenai rata-rata stanting di Jawa Timur, Puti tidak memberikan jawaban mengenai hal itu tetapi hanya memperkuat apa yang ia argumentasikan sebelumnya. Puti mengatakan mengenai fakta, tetapi apa yang ia utarakan sebelumnya hanyalah argumennya sendiri mengenai masyarakat Trenggalek tanpa data yang jelas. Dia juga terus menyerang dengan argumen lanjutnya mengenai 
stanting dan kelemahan Emil. Pelanggaran maksim relevansi dapat dilihat dalam kutipan transkrip berikut.

Emil : "Rata-rata Jawa Timur berapa stanting?"

Puti : "Saya berbicara mengenai fakta mas Emil".

Emil : "Rata-rata Jawa Timur berapa stanting?, gak bisa jawab kaan!"

Puti : "Mas Emil harus mengakui bahwa di trenggalek ada desa stanting, artinya Mas Emil tidak lihat, tidak langsung melihat masyarakat dan rakyatnya, mengapa bisa ada stanting di sana, kalau Mas Emil mengetahui pasti Mas Emil akan melihat".

\section{Pelanggaran Maksim Cara/Pelaksanaan}

Pelanggaran maksim cara dapat dilihat dari cara berbicara tidak langsung, kabur, taksa, berlebih-lebihan dan tidak runtut. Pada debat yang dianalisis hal ini terjadi pada saat Puti bertanya mengenai progam yang dilaksanakan oleh Emil. Puti tidak langsung kepada apa yang ingin disampaikan melainkan berbelit-belit dengan membahas mengenai tingkat kemiskinan di Kabupaten Trenggalek. Hal tersebut membuat jawaban yang diberikn juga tidak pada pertanyaan inti karena pertanyaan idak langsung diutarakan sehingga lawan tutur menjadi terfokus pada penjelasan awal yang disampaikanoleh penutur. Dapat dilihat pada kutipan transkrip berikut.

Puti: "Baik, terima kasih, Mas Emil ada satu pertanyaan yang akan saya sampaikan pada Mas Emil. Kemarin itu saya sempat jalan-jalan juga menyapa warga Kabupaten Trenggalek. Lalu saya melihat bahwa di dalam data BPS 2016 tingkat kemiskinan di Kabupaten Trenggalek itu naik 0,17 $\%$, lalu kemudian 2017 tingkat pengangguran terbuka Kabupaten Trenggalek juga naik mas 37\% dari 1960 sampai ke angka 13.000. sementara saya tahu mas emil punya program yang begitu baik adalah Milenial job center lalu bagaimana komitmen mas Emil?".

\section{PENUTUP}

Berdasrkan analisis yang telah dilaksanakan mengenai pelanggaran prinsip kerjasama dalam debat CAWAGUB Jawa Timur 2018 ditemukan beberapa pelanggaran. Setiap maksim dalam prinsip kerjasama ditemukan bukti pelanggaran. Dapat dikatan pula dalam sebuah debat sering ditemua pelanggaran ptinsip kerjasama. Pelanggran yang terjadi meliputi pelanggaran maksim kuantitas, maksim kualitas, maksim relevansi, dan maksim cara/pelaksanaan. 
Pelanggaran maksim kuantitas terjadi saat Emil menjawab pertanyaaan dari Puti dengan berlebihan. Pelanggaran maksim kualitas terjadi saat Puti menyebutkan desa yang dikunjungi dengan penggunaan kata kalau tidak salah. Pelanggaran maksim relevansi terjadi saat Emil menanyakan mengenai rata-rata stanting Jawa Timur dan Puti tidak menjawab pertanyaan tersebut. Sedangkan pelanggaran maksim cara terjadi saat Puti bertanya tetapi terlalu bertele-tele dengan menjelaskan hal lain di luar pertanyaan yang disampaiakan.

\section{DAFTAR RUJUKAN}

Chaer, Abdul.2012. Linguistik Umum. Jakarta: Rineka Cipta.

Nadar, F.X. 2013. Pragmatik dan Penelitian Pragmatik. Yogyakarta: Graha Ilmu.

Ruisah. 2015. Analisis Percakapan dalam Program Debat Kandidat Pemilihan Kepala Daerah Jawa Timur. Jurnal Ilmu Komunikasi, Vol. 3 No. 2 Desember 2015. (diakses pada 29 Juni 2018).

Wijana, I Dewa Putu. 1996. Dasar-Dasar Pragmatik. Yogyakarta: Andi Offset. 